\title{
The Pb-Zn (Ba) Nonsulfide Mineralizations at Bou Caïd (Ouarsenis, Algeria): Mineralogy, Isotope Geochemistry, and Genetic Inferences
}

\author{
Hassina Louha ${ }^{1}$, Giuseppina Balassone ${ }^{2,3, * \mathbb{D}}$, Abdelhak Boutaleb ${ }^{1}$, Maria Boni ${ }^{2,4}$, Michael M. Joachimski ${ }^{5}$ and \\ Nicola Mondillo 2,4
}

check for updates

Citation: Louha, H.; Balassone, G.; Boutaleb, A.; Boni, M.; Joachimski, M.M.; Mondillo, N. The Pb-Zn (Ba) Nonsulfide Mineralizations at Bou Caïd (Ouarsenis, Algeria): Mineralogy, Isotope Geochemistry, and Genetic Inferences. Minerals 2021, 11, 687. https://doi.org/10.3390/ $\min 11070687$

Academic Editor: Huan Li

Received: 26 April 2021

Accepted: 19 June 2021

Published: 26 June 2021

Publisher's Note: MDPI stays neutral with regard to jurisdictional claims in published maps and institutional affiliations.

Copyright: (c) 2021 by the authors. Licensee MDPI, Basel, Switzerland. This article is an open access article distributed under the terms and conditions of the Creative Commons Attribution (CC BY) license (https:/ / creativecommons.org/licenses/by/ $4.0 /)$.
1 Laboratoire de Métallogénie et Magmatisme de l'Algérie, FSTGAT-USTHB, BP 32, El Alia 16111, Algeria; hassinalouha@yahoo.fr (H.L.); aboutaleb@usthb.dz (A.B.)

2 Dipartimento di Scienze della Terra, dell'Ambiente e delle Risorse, Università Federico II, Complesso Universitario Monte S. Angelo, via Vicinale Cupa Cintia 26, 80126 Napoli, Italy; boni@unina.it (M.B.); nicola.mondillo@unina.it (N.M.)

3 Istituto Nazionale di Geofisica e Vulcanologia, Osservatorio Vesuviano, via Diocleziano 236, 80124 Napoli, Italy

4 Department of Earth Sciences, Natural History Museum, Cromwell Road, London SW7 5BD, UK

5 GeoZentrum Nordbayern, Friedrich-Alexander University of Erlangen-Nuremberg, Schlossgarten 5, 91054 Erlangen, Germany; michael.joachimski@fau.de

* Correspondence: balasson@unina.it

\begin{abstract}
The ore deposits of Bou Caïd (Ouarsenis, Algeria) occur in Jurassic and Cretaceous sedimentary rocks. The barite and $\mathrm{Pb}-\mathrm{Zn}(\mathrm{Fe}, \mathrm{Cu}$, and $\mathrm{F})$ ore deposits of Bou Caïd belong to vein- and karst-type. The mineralization is represented in the whole area by a mixture of barite (currently still exploited) and nonsulfides consisting of hemimorphite, smithsonite, cerussite, hydrozincite, and Feoxy-hydroxides, with remnants of galena and sphalerite in variable proportions. Mineralogical and geochemical analyses were carried out on the Bou Caïd nonsulfides. Several samples representing nonsulfide mineralization (Grand Pic and at Srâa Abdelkader) were subjected to a multidisciplinary analytical approach, using optical microscopy (OM), powder X-ray diffraction (PXRD), Scanning Electron Microscopy with Energy Dispersive Spectrometry (SEM-EDS). Nonsulfide mineralization consists of a mixture of hemimorphite, hydrozincite, smithsonite, cerussite, and Fe-oxy-hydroxides, often with zebra-like textures. In the proposed paragenetic scheme, covellite and chalcocite are followed by cerussite, jarosite, smithsonite, and hydrozincite. Then, hemimorphite crystallizes, accompanied by mimetite, traces of malachite and clay minerals (also Zn-bearing), precipitate. Fe(Mn)-oxy-hydroxides can form during various phases of the supergene stage. Small amounts of late barite can be related to partial remobilization and occur as reprecipitation products. Stable isotope analyses were performed on the calcites and metal carbonates of the supergene ores. Carbon and oxygen isotope values of smithsonite and hydrozincite were comparable to published supergene $\mathrm{Zn}$ carbonate data. The isotope values of the Bou Caid calcites fell both into the hydrothermal carbonate and in the supergene fields.
\end{abstract}

Keywords: Bou Caïd; Algeria; non sulfide ores; mineralogy; isotope geochemistry

\section{Introduction}

Northern Algeria is part of the Alpine Atlas mountain ranges, extending from west to east through Morocco, Algeria, and Tunisia, along the Mediterranean coast. In this mountain belt, Triassic to upper Miocene carbonate rocks host numerous $\mathrm{Zn}-\mathrm{Pb}$ sulfide deposits, some of them genetically representing varieties of the typical Mississippi Valleytype (MVT) ores [1].

The presented work aimed to conduct a mineralogical and geochemical study of nonsulfide ore deposits from Bou Caïd (northwestern Algeria). This ore field is located in 
the eastern part of the massif of Ouarsenis, $250 \mathrm{~km}$ south-west from Algiers and $50 \mathrm{~km}$ from Chélif. The mineralizations of the Bou Caïd district are mainly found in Jurassic carbonate rocks (Early-Lower, locally also Late Jurassic); they occur as vein- and karst filling-deposit types. $\mathrm{Zn}-\mathrm{Pb}$ ore deposits occur at Srâa Abd El Kader, Grand Pic, Belkheiret and Rockba. The primary sulfides are essentially composed of galena and sphalerite associated with barite, whereas oxidized minerals are represented by variable amounts of $\mathrm{Zn}$-silicates and $\mathrm{Zn}$-carbonates (hemimorphite, hydrozincite, smithsonite, cerussite) with widespread Fe-oxy-hydroxides [2].

Twenty-five samples were collected from two sites, i.e., Srâa Abd El Kader and Grand Pic; they are mainly represented by the nonsulfide-bearing assemblage, with few samples also originating from the primary sulfides mineralization of the Bou Caïd orefield. A multidisciplinary analytical approach was used including polarizing microscopy $(\mathrm{OM})$, powder X-ray diffraction (PXRD), Scanning Electron Microscopy-Energy Dispersive Spectroscopy SEM-EDS, in order to obtain a mineralogical characterization of the supergene ore. Stable isotope (C-O) analyses were also performed on selected samples (mainly from the supergene ore) to shed new light on the genesis of the Bou Caïd non sulfide carbonates, and on their relationships with the primary mineralized associations.

\section{Geological Background}

\subsection{Geology of Northern Algeria and the Ouarsenis Area}

Northern Algeria, located at the boundary between the Eurasian and African plates [3], is part of the Maghrebides Alpine chain that forms the North African margin. The Tell-Rif (Tell in Algeria and Tunisia, and Rif in Morocco) or Maghrebides is the orogenic system fringing the Western Mediterranean basins to the south $[4,5]$. This system comprises three major tectonic-palaeogeographic zones, i.e., from north to south: (1) the internal zones originated from the former northern European margin of the Ligurian-Maghrebian Tethys (LMT) [4]; (2) the "Flysch zone", regarded as the former sedimentary cover of the LMT and (3) the external zones that represent the former North African passive margin of the LMT.

The following geological domains can be identified (from north to south): the internal structure of the Kabylies, the Tell system (so-called External Tell or Tellian Atlas), the Atlas system (High Plateaus, the Saharan Atlas, and Aurès), and the Saharan platform (Figure 1a). Further details can be found in [4,6-10].

The area of Ouarsenis is located in the central part of the Tellian Atlas, at the highest part of the mountainous system of the Tell. The Grand Pic massif, the Srâa Abdelkader massif, the Belkheïrat massif, the Batha and Rokba can be differentiated. In the north, the massif of Ouarsenis is separated by the valley of Oued Chélif, while it is demarcated in the south by the Hauts plateau (Figure 1b). The stratigraphy of this area comprises formations ranging in age from Paleozoic to Cenozoic [11]. The Paleozoic rocks are magmatic (mainly granites and granodiorites) and metamorphic (amphibolites and gneiss) [12]. The basement is not exposed, but some basement fragments can be found as insets within the Triassic gypsum formations or Miocene marls [12,13]. The Triassic rocks are similar throughout the Tellian Atlas and consist of variegated clays and gypsum [12], while the Jurassic is mainly represented by carbonates (dolomites, dolomitic limestones, and limestones). The oldest Jurassic formation, with a thickness of few meters, consists of an alternance of marly limestone considered to be of the early Liassic age [14-16]. It is followed by about $10 \mathrm{~m}$ thick, late Toarcian arenaceous sediments. Early Cretaceous rocks are characterized by alternations of marly limestones and clays with quartz-rich levels, especially observed in Albian turbidites [17]. Cenozoic deposits are mainly developed as gray marls. From Paleocene to early Eocene, marly limestones occasionally associated with sandy-glauconitic levels occur [13,18]. In the easternmost part of the Ouarsenis, the Oligocene sediments are represented by the Numidian Flysch. The Miocene to Quaternary lithological formations unconformably covers the older units. They were deposited subsequently to thrusting of the internal zones, turbidite nappes, and Tellian nappes building up large post-nappe basins, as in the case of the WSW-ENE oriented Chelif Basin [19]. 


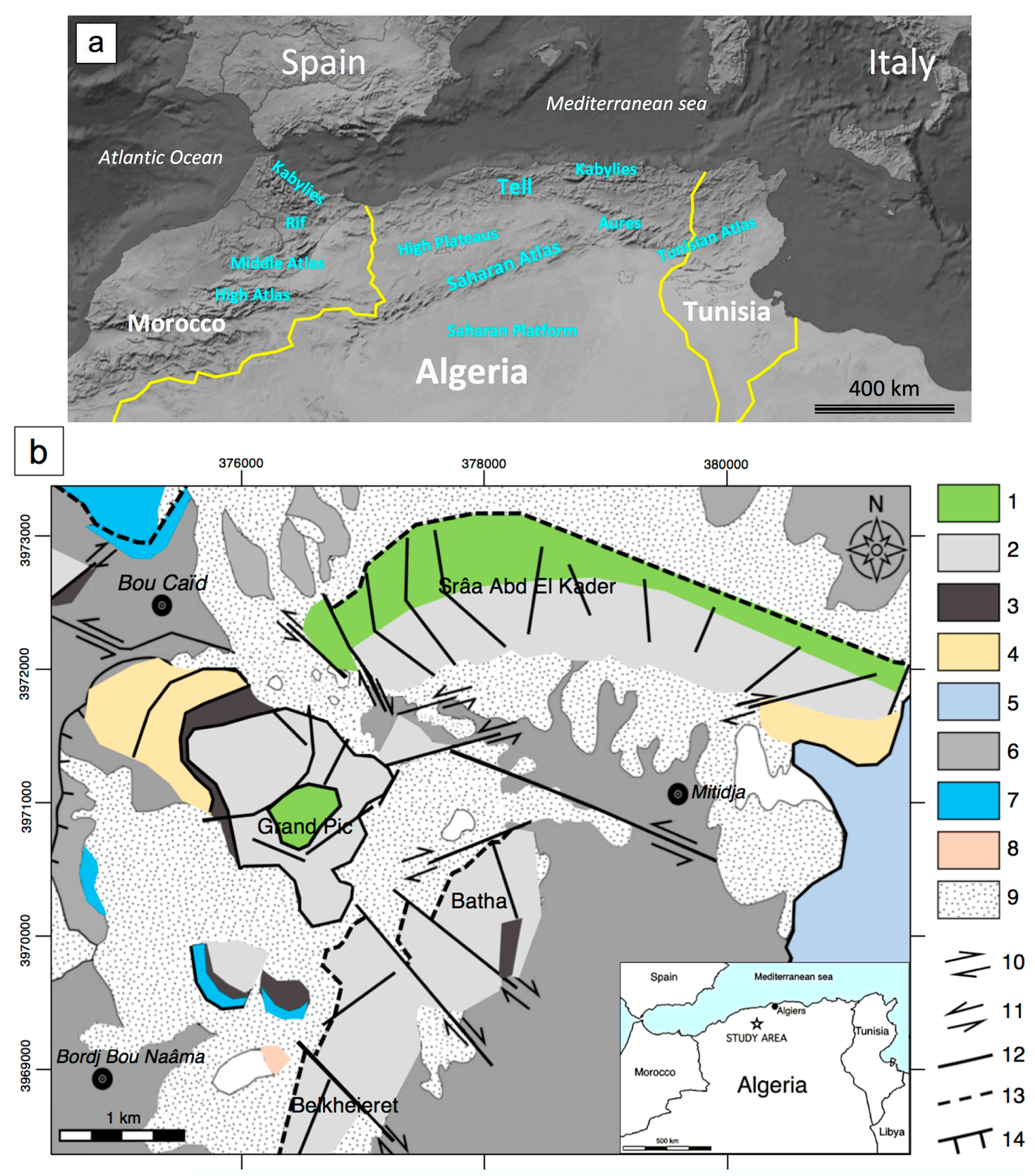

Figure 1. (a) Structural domains of North Africa (see text). (b) Schematic map of the Ouarsenis culminating zone (adapted after [11]). 1: Early Liassic; 2: Late and Middle Liassic; 3: Oxfordian; 4: Tithonian and Berriasian to Hauterivian; 5: Albian; 6: Barremian; 7: Cenomanian; 8: Early Miocene; 9: Quaternary; 10: dextral strike-slip; 11: sinistral strike-slip; 12: fault; 13: tectonic contact; 14: thrust.

\subsection{The ores of the Ouarsenis and Bou Caïd Area}

The ore deposits of the Ouarsenis and the Bou Caïd area occur in Jurassic and Cretaceous sedimentary rocks. The Jurassic rocks are represented by dolomites and fine-grained, brecciated dolomitic limestone of $100 \mathrm{~m}$ to $400 \mathrm{~m}$ in thickness, by $300-400 \mathrm{~m}$ thick massive limestones, 50-110 m thick laminated limestones, sandstones, and conglomerates, and 40$200 \mathrm{~m}$ thick limestones and marls. The Cretaceous sediments include Neocomian 50-150 m thick slaty marls and marly limestones and Albian slaty clays. The $\mathrm{Zn}-\mathrm{Pb}$ ore bodies of the areas of Abdelkader, Grand Pic, Belkheiret, and Rockba (Figure 1) are tabular, branched, or with variable shapes. The middle section of these bodies varies from 20 to $150 \mathrm{~m}^{2}$, rarely reaching $1000 \mathrm{~m}^{2}$ or more. The thickness of the bodies varies from 0.15 to $5.0-6.0 \mathrm{~m}$, 
with an average value of $0.6-1 \mathrm{~m}$. The ores were subdivided by [2] into three types, i.e., sulfides, oxides, and barite, genetically related to primary and secondary ore deposition processes. Generally, the ore mineral assemblage is represented in the whole area by a mixture of barite, smithsonite, cerussite, limonite (Fe-oxy-hydroxides), remnants of galena, and sphalerite in variable proportions. The primary sulfides are associated with barite, calcite, and subordinate pyrite, marcasite, and quartz. Traces of arsenopyrite, chalcopyrite, freibergite, boulangerite, miargyrite, proustite, melnikovite (fine-grained colloform to banded pyrite and/or marcasite), jordanite, fluorite, and aragonite, have also been detected. Prevailing secondary minerals (as carbonates and oxides) are smithsonite, cerussite, and Fe-oxy-hydroxides [2].

The Bou Caïd orefield, which represents the study area, is located in the eastern part of the massif of Ouarsenis, $250 \mathrm{~km}$ south-west from Algiers (Figure 1). The mineralizations were discovered in 1842, and the exploitation of the polymetallic deposits (with $20 \% \mathrm{Zn}$ and $15 \% \mathrm{~Pb}$ average content) started in 1950. After the independence of Algeria in 1962, SONAREM (Société Nationale de Recherches et d'Exploitation Minières) undertook a prospection campaign in 1967, while the exploitation continued until 1975, when the main mineralizations were exhausted [20]. In 1975 an extensive barite body (850 m in length) was discovered, and currently, barite mining is still active in various underground mines (Sidi Lakhdar, North, Sidi Belabbes, Colonne 2, Belkheiret, Ammal, Sidi Diaber, and Sidi Ouadah). The barite and $\mathrm{Pb}-\mathrm{Zn}(\mathrm{Fe}, \mathrm{Cu}$, and $\mathrm{F})$ ore deposits of Bou Caïd are of the veinand karst-type [20,21]; the main orebodies are at Sidi Ouadah, Sidi Omar, Ammal, and Sidi Djaber, in the massif of Srâa Abd El Kader and in the massif of Grand Pic (Figures 2 and 3).
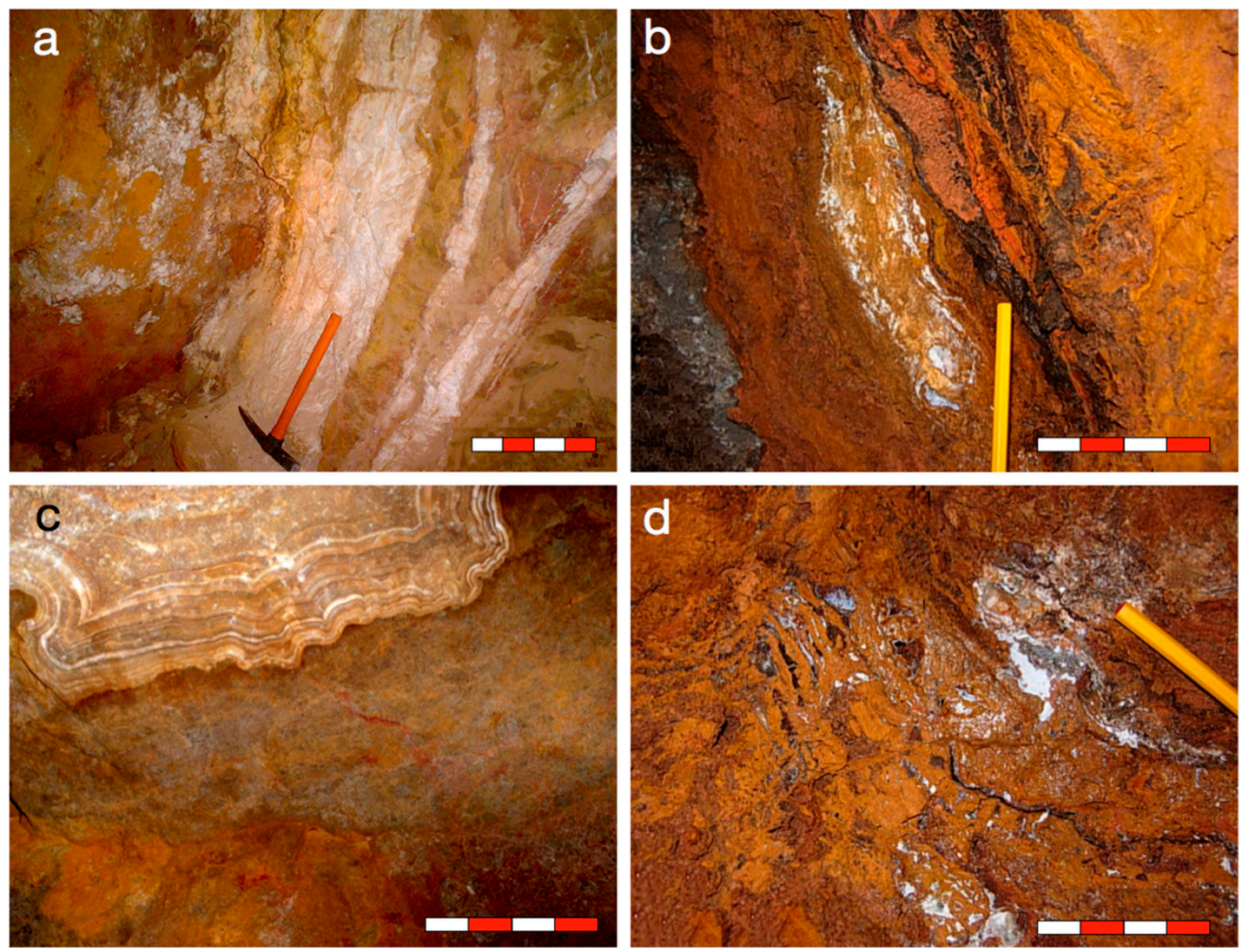

Figure 2. (a) The vein ore at Srâa Abd El Kader and (b-d) the karst type at Grand Pic [20,21]. Scale bar = $20 \mathrm{~cm}$ in (a), $10 \mathrm{~cm}$ in (b), $35 \mathrm{~cm}$ in (c), and $10 \mathrm{~cm}$ in (d). 


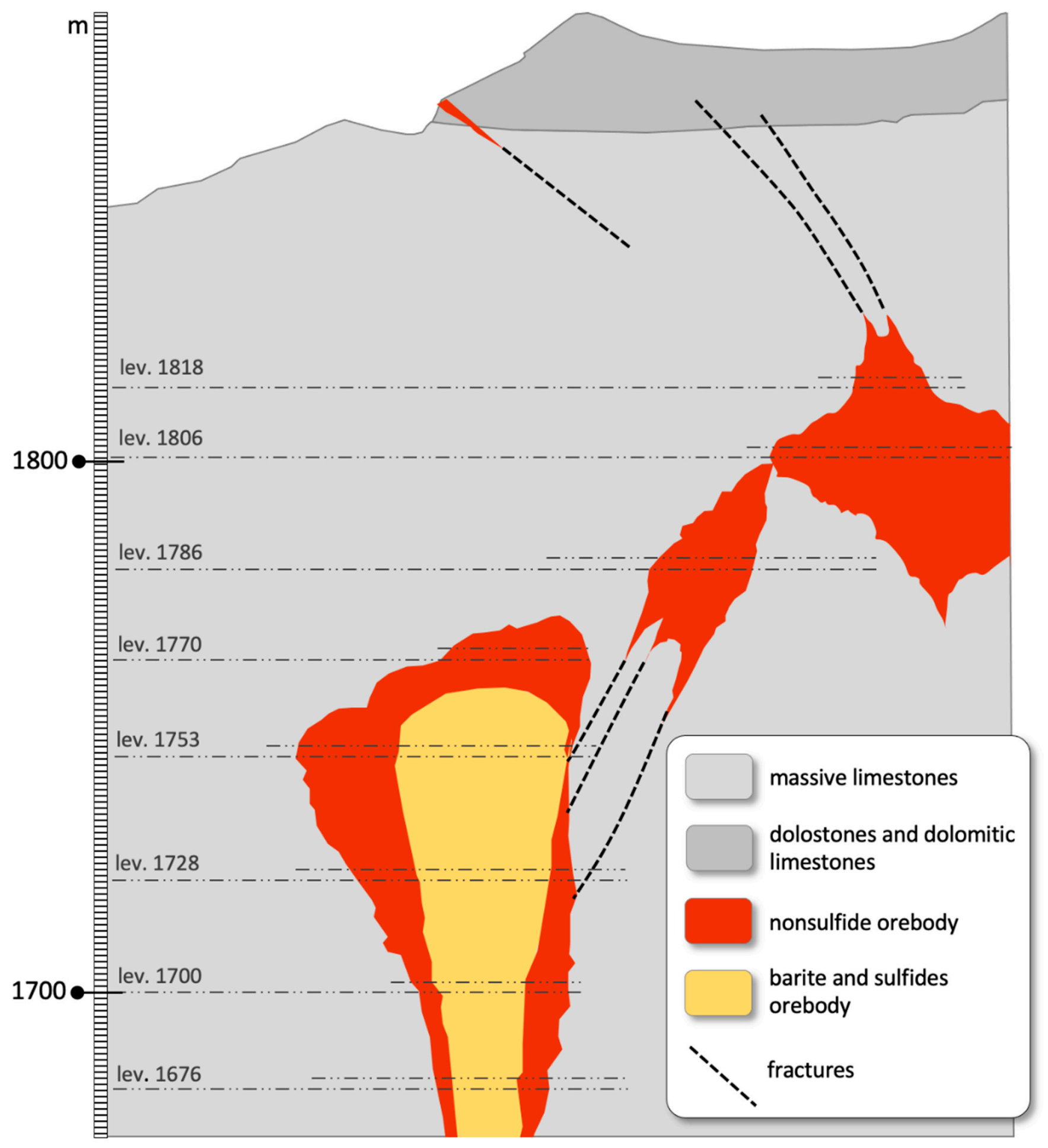

Figure 3. Grand Pic vertical section (adapted from [21], and the references therein).

Most of the mineralizations occur in the lowermost Jurassic limestones and only rarely in the Late Jurassic sediments. Very few mineralizations are found in limestones of the Early Cretaceous age (Neocomian), which is also less tectonized. At Srâa Abdelkader and the Grand Pic, the vein mineralization mainly consist of barite. 


\section{Materials and Methods}

The location of the investigated twenty-five samples is shown in Figure 4. Mineralogical analyses were carried out by powder X-ray diffraction (PXRD) by means of a Seifert-GE ID3003 diffractometer (CuK $\alpha$ radiation, Ni-filtered at $40 \mathrm{kV}$ and $30 \mathrm{~mA}$, in the $3-80^{\circ} 2 \theta$ range, a step scan $0.02^{\circ}$, and $10 \mathrm{~s} /$ steps) at the Dipartimento di Scienze della Terra, dell'Ambiente e delle Risorse (DiSTAR) University of Naples Federico II (Italy). In order to identify the different phases, the RayfleX (GE) software package was used (Version 2.336, GE Inspection Technologies, Germany).

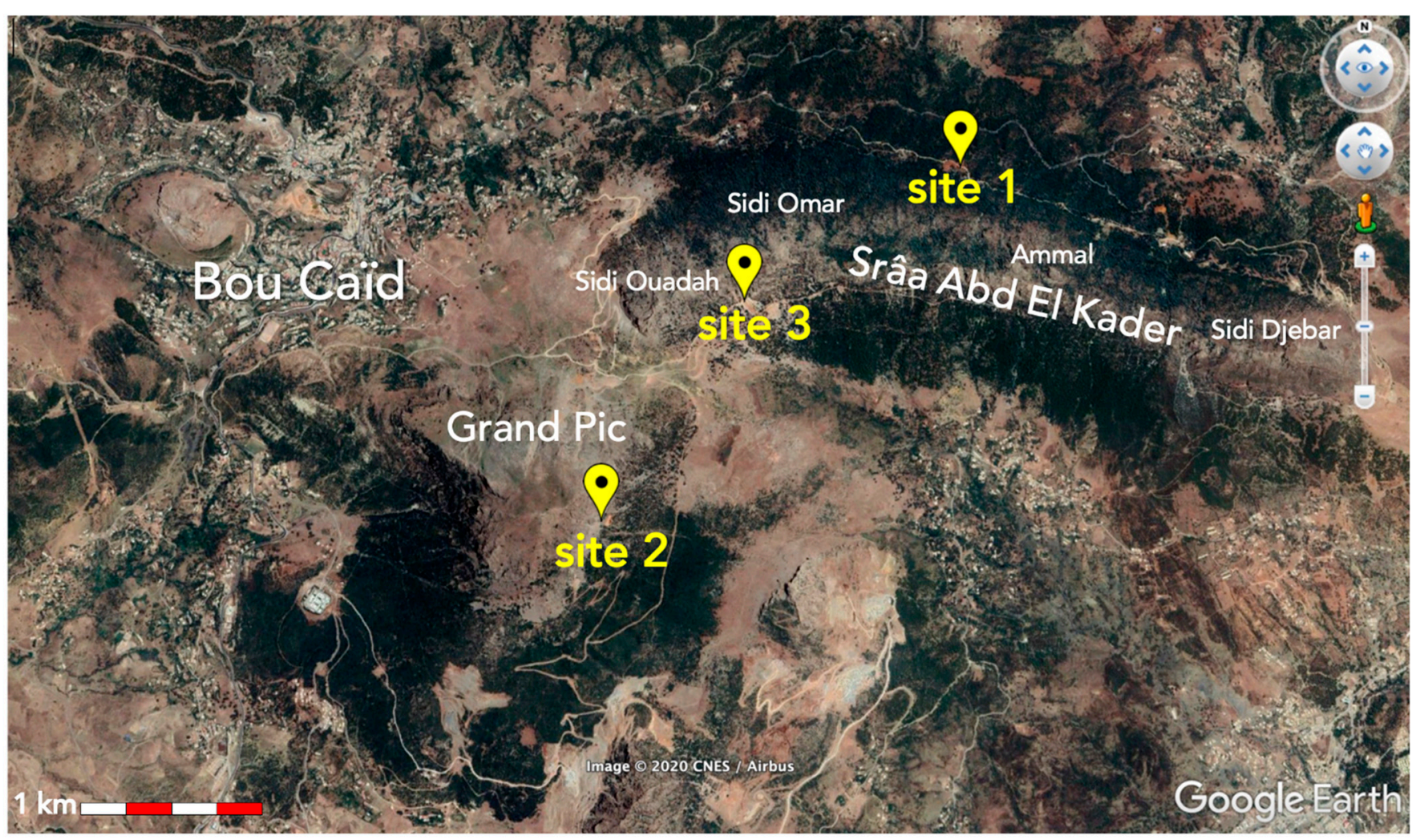

Figure 4. The three sampling sites; their GPS coordinates (latitude, longitude, and elevation) are site $1: 35^{\circ} 53^{\prime} 36.30^{\prime \prime} \mathrm{N}$, $1^{\circ} 39^{\prime} 34.52^{\prime \prime} \mathrm{E}, 1500 \mathrm{~m}$; site 2: $35^{\circ} 52^{\prime} 26.85^{\prime \prime} \mathrm{N}, 1^{\circ} 38^{\prime} 09.45^{\prime \prime} \mathrm{E}, 1710 \mathrm{~m}$; site 3: $35^{\circ} 53^{\prime} 09.31^{\prime \prime} \mathrm{N}, 1^{\circ} 38^{\prime} 42.57^{\prime \prime} \mathrm{E}, 1567 \mathrm{~m}$.

Micromorphological and chemical analyses were carried out by Scanning Electron Microscopy with Energy Dispersive Spectrometry (SEM-EDS), using a JEOL JSM5310 electron microscope (DiSTAR) equipped with an Oxford EDS, an INCA X-stream pulse processor (4.08 version Inca software, Oxford Instruments Anl. Ltd., Oxford, UK), and the following operating conditions: acceleration voltage of $15 \mathrm{kV}, 50-100 \mu \mathrm{A}$ filament current, variable spot size and a working distance of $20 \mathrm{~mm}$. The reference standards for quantitative microanalysis (detection limits of the analyzed elements below $0.1 \%$ ) were: anorthoclase $(\mathrm{Si}, \mathrm{Al}$, and $\mathrm{Na})$, diopside $(\mathrm{Ca})$, microcline $(\mathrm{K})$, rutile $(\mathrm{Ti})$, fayalite $(\mathrm{Fe})$, olivine $(\mathrm{Mg})$, serandite $(\mathrm{Mn})$, sphalerite $(\mathrm{Zn})$, benitoite $(\mathrm{Ba})$, celestite $(\mathrm{Sr})$, fluorite $(\mathrm{F})$, halite $(\mathrm{Cl})$, pyrite, $(\mathrm{S})$, galena $(\mathrm{Pb})$, and copper metal $(\mathrm{Cu})$.

Carbon and oxygen isotope analyses were performed on $\mathrm{Zn}$-Ca carbonates, handpicked from different zones, both on the mineralized samples and calcite from the gangue. The analyses were carried out at the GeoZentrum Nordbayern of the University of ErlangenNuremberg (Germany). Powdered carbonate samples were reacted with phosphoric acid at $70{ }^{\circ} \mathrm{C}$, using a GasBench II connected to a Thermo Finnigan V Plus isotope ratio mass spectrometer. The carbon and oxygen isotope results are expressed as delta values in per mile $(\%)$, relative to Vienna Peedee belemnite (V-PDB) and Vienna standard mean ocean water (V-SMOW), respectively, by assigning a $\delta^{13} \mathrm{C}$ value of $+1.95 \%$ to NBS19 and $-46.6 \%$ 
to LSVEC and $\delta^{18} \mathrm{O}$ values of $-2.20 \%$ to NBS19 and $-23.2 \%$ to NBS18. Reproducibility was checked by replicate analysis of laboratory standards and was better than $\pm 0.07 \%$ o $(1 \sigma)$ for both carbon and oxygen isotope analyses. Oxygen isotope values were corrected using the phosphoric acid fractionation factors given by [22] for calcite and [23] for smithsonite and cerussite. As the phosphoric acid fractionation factor for hydrozincite has not been determined yet, we adopted the smithsonite acid fractionation factor [23] as in earlier studies (e.g., [24-26]).

\section{Results}

The mineral associations carried out from combined PXRD and SEM-EDS analyses are given in Table 1.

Table 1. Origin and mineral assemblages of studied samples inferred by PXRD and SEM-EDS analyses.

\begin{tabular}{|c|c|c|}
\hline Sample ID & Sample Location $^{1}$ & Main Mineral Assemblage ${ }^{\S}$ \\
\hline ECH 1 & site 1-Srâa Abd El Kader & hemimorphite, hydrozincite, Fe-(oxy)-hydroxides, and barite \\
\hline $\mathrm{ECH} 2$ & site 1—Srâa Abd El Kader & hemimorphite and Fe-(oxy)-hydroxides \\
\hline $\mathrm{ECH} 3$ & site 1—Srâa Abd El Kader & hemimorphite, goethite, hematite, and barite \\
\hline $\mathrm{ECH} 4$ & site 3-Srâa Abd El Kader & $\begin{array}{c}\text { barite, galena, calcite, quartz, cerussite, Fe-(oxy)-hydroxides magnetite, } \\
\text { and sulfur }\end{array}$ \\
\hline ECH 5 & site 3-Srâa Abd El Kader & smithsonite, hydrozincite, cerussite, barite, galena, and dolomite \\
\hline ECH 6 & site 1-Srâa Abd El Kader & hemimorphite and Fe-(oxy)-hydroxides \\
\hline $\mathrm{ECH} 7$ & site $2-$ Grand Pic & calcite, smithsonite, and Fe-(oxy)-hydroxides \\
\hline $\mathrm{ECH} 8$ & site $2-$ Grand Pic & calcite, barite, and Fe-(oxy)-hydroxides \\
\hline ECH 9 & site $2-$ Grand Pic & barite, and fluorite \\
\hline ECH 10 & site 2-Grand Pic & $\begin{array}{c}\text { calcite, barite, cerussite, } \mathrm{Mn}(\mathrm{Fe})-(\mathrm{oxy}) \text {-hydroxides, and ( } \mathrm{Zn} \text { )clay } \\
\text { minerals }\end{array}$ \\
\hline ECH 11 & site 1—Srâa Abd El Kader & hemimorphite, goethite, barite, cerussite, and sphalerite \\
\hline ECH 12 & site 1—Srâa Abd El Kader & $\begin{array}{c}\text { hemimorphite, hydrozincite, goethite, calcite, barite, and ( } \mathrm{Zn} \text { )clay } \\
\text { minerals }\end{array}$ \\
\hline $\mathrm{ECH} 14$ & site $2-$ Grand Pic & calcite, quartz, barite, Fe-(oxy)-hydroxides, and malachite \\
\hline ECH 15 & site 1—Srâa Abd El Kader & hemimorphite, barite, and ( $\mathrm{Zn}$ )clay minerals \\
\hline ECH 16 & site $2-$ Grand Pic & calcite, Fe-(oxy)-hydroxides, and cerussite \\
\hline $\mathrm{ECH} 17$ & site 1—Srâa Abd El Kader & calcite, barite, $(\mathrm{Zn})$ clay minerals, and mimetite \\
\hline $\mathrm{ECH} 18$ & site 1—Srâa Abd El Kader & hemimorphite, cerussite, barite, galena, and ( $\mathrm{Zn}$ )clay minerals \\
\hline ECH 19 & site 1—Srâa Abd El Kader & hemimorphite, Fe-(oxy)-hydroxides, and (Zn)clay minerals \\
\hline ECH 20 & site 1—Srâa Abd El Kader & $\begin{array}{c}\text { hemimorphite, Fe-(oxy)-hydroxides, quartz, } \mathrm{Mn}(\mathrm{Zn}) \text {-(oxy)-hydroxides, } \\
\text { barite, cerussite, and (Zn)clays }\end{array}$ \\
\hline ECH 21 & site 3-Srâa Abd El Kader & calcite \\
\hline ECH 22 & site 3-Srâa Abd El Kader & calcite, quartz, and barite \\
\hline $\mathrm{ECH} 23$ & site 3-Srâa Abd El Kader & calcite and sphalerite \\
\hline ECH 24 & site $2-$ Grand Pic & hydrozincite and barite \\
\hline ECH 25 & site $2-$ Grand Pic & smithsonite, hydrozincite, cerussite, calcite and quartz \\
\hline $\mathrm{ECH} 30$ & site 3-Srâa Abd El Kader & calcite \\
\hline ECH 33 & site $2-$ Grand Pic & hydrozincite \\
\hline
\end{tabular}

${ }^{1}$ See Figure $4 .{ }^{\S}$ Primary ore-related or mixed sulfide-supergene mineral associations are indicated in Italics.

The investigated nonsulfide-bearing samples show various textures and appear banded with alternations of Fe-oxy-hydroxides and Zn-carbonates and Zn-silicates (Figure 5a,e,f), drusiform with well-formed hemimorphite crystals on iron-rich crusts (Figure $5 c, d$ ), or massive. The primary barite-galena mineralization is shown in Figure $5 b$. 


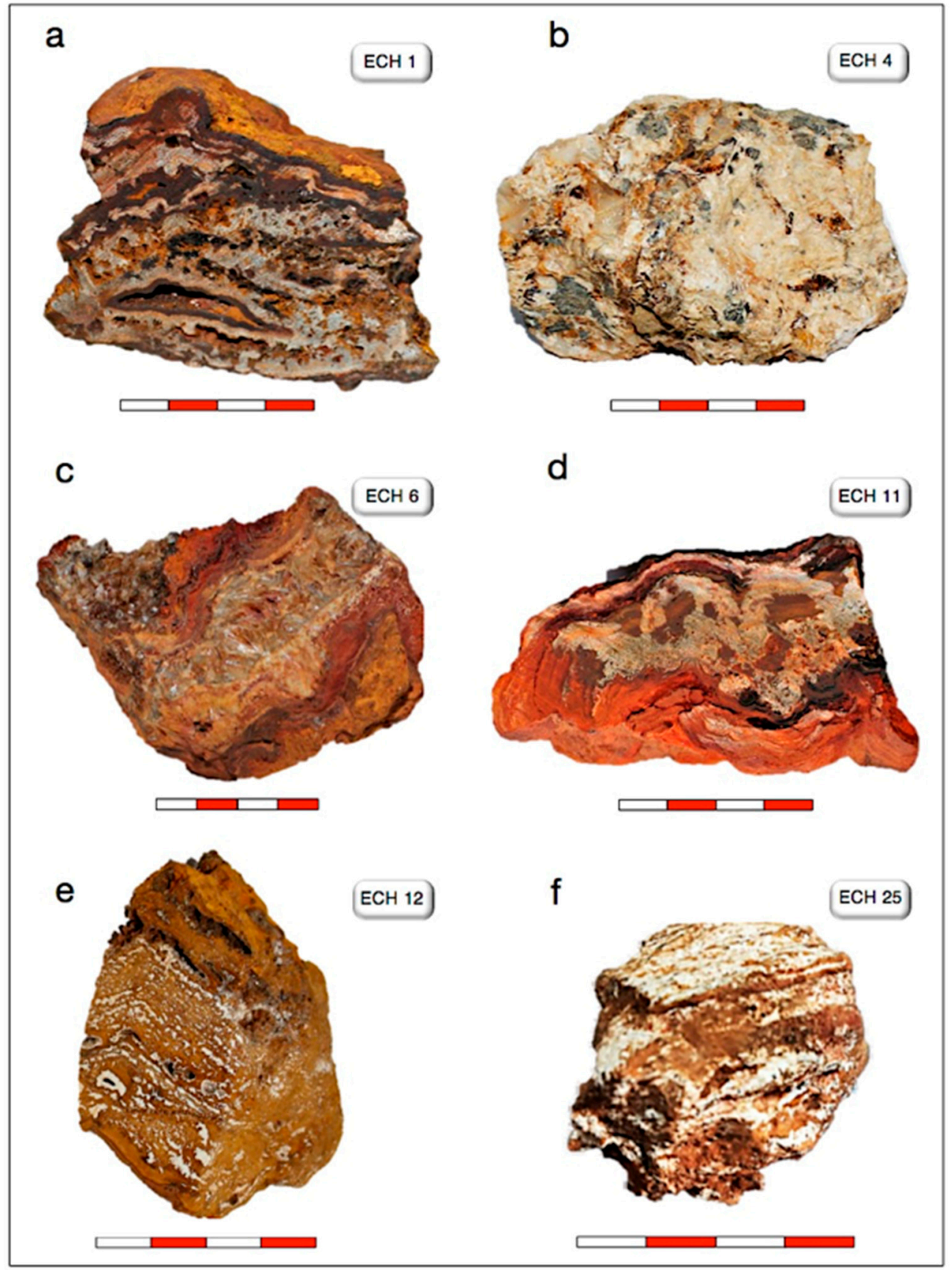

Figure 5. The typical textures of selected nonsulfide samples from the Bou Caïd area, mainly ranging from banded $(\mathbf{a}, \mathbf{e}, \mathbf{f})$ to drusiform $(\mathbf{c}, \mathbf{d})$. A barite-galena-bearing rock from the primary mineralization is also shown in $(\mathbf{b})$. Scale bar $=4 \mathrm{~cm}$.

As stated above, the majority of the samples originate from the supergene orebody, whereas only some samples, e.g., 9, 21, 22, and 23, represented the primary (sulfide-bearing) mineralization. Sample ECH 4 shows a mixed mineral assemblage, representing a transition zone.

Barite remnants were present in almost all samples. Sulfides could locally occur in the nonsulfide-bearing ores. The nonsulfide assemblage contained variable amounts of $\mathrm{Zn}$ minerals, mostly consisting of hemimorphite, smithsonite, and hydrozincite; the Fe-(oxy)-hydroxides (goethite, hematite) are ubiquitous. Malachite and mimetite have also been detected in trace amounts, as well as clay minerals (smectites and illite). Cerussite is abundant, and also calcite, quartz, and Mn-(Zn)-(oxy)-hydroxides occurred in significant 
amounts. Fluorite was detected only in one sample (ECH 9), associated with the primary ore minerals.

Figure 6 shows optical microscopy micrographs of selected samples, which represent the most widespread microstructures. Microcrystalline cerussite could be found with tabular barite (Figure 6a,c) and could substitute galena. Smithsonite was commonly anhedral and occurred as disseminations and/or fracture lining (Figure 6b); it was found as inclusions in hemimorphite crystals and sometimes appeared to be replaced by the Zn-silicate. Microcrystalline smithsonite could replace dolomite. Hydrozincite occurred as rounded masses and as vug filling (Figure 6d,e). Hemimorphite was commonly observed as large crystals (Figure 6f); it often forms reddish crusts and crystalline aggregates. All the secondary $\mathrm{Zn}(\mathrm{Pb})$ carbonate and silicate minerals were often surrounded by goethite. Calcite crystals as gangue minerals were seen in various samples.
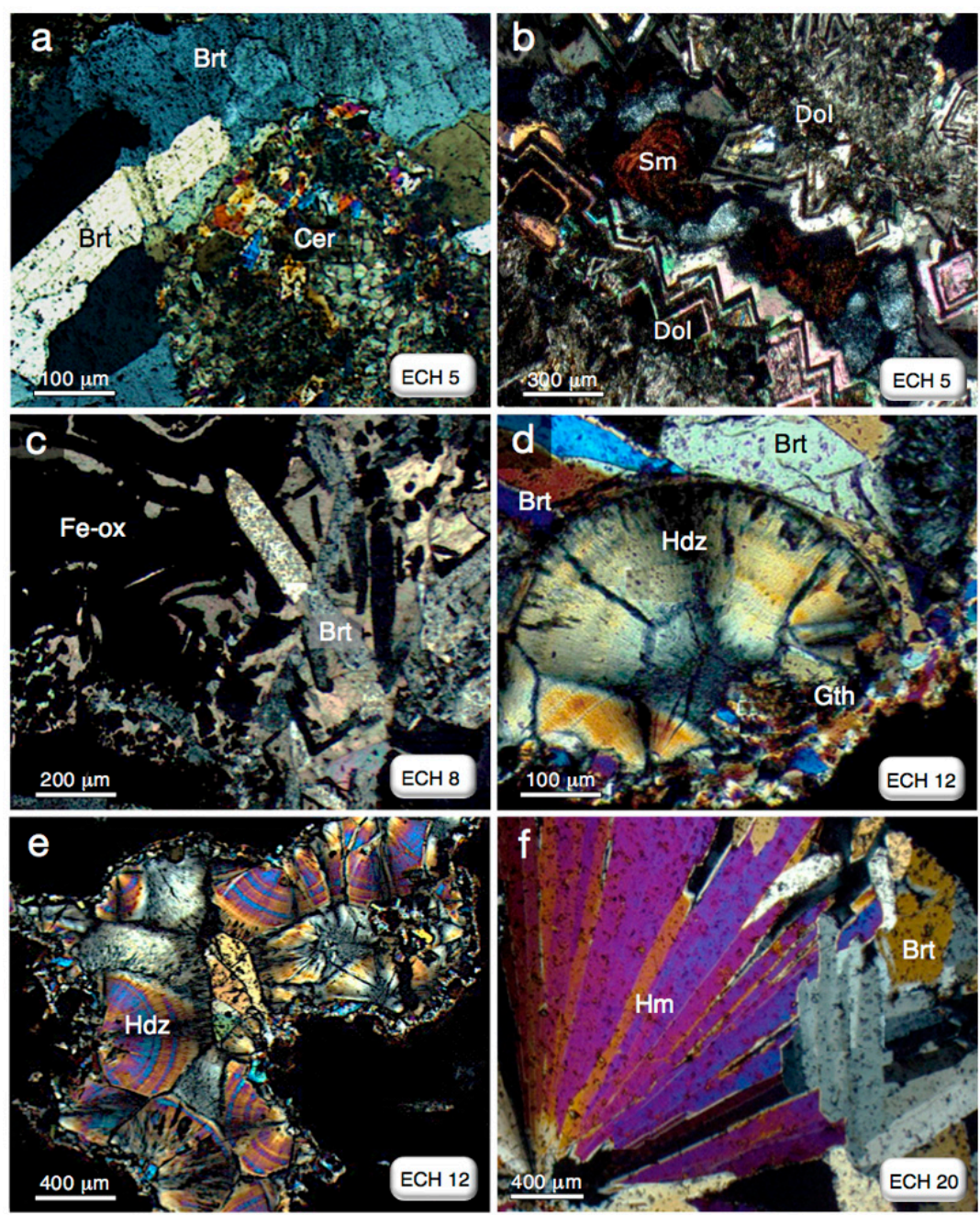

Figure 6. Micrographs of selected nonsulfide samples, observed in a thin section at polarizing microscope $(\mathrm{N}+)$. (a) Fine-grained cerussite among relic barite crystals. (b) Smithsonite as filling in dolomite. (c) Tabular barite with late goethite. (d,e) Botryoidal hydrozincite. (f) Euhedral hemimorphite crystals with relic barite. Brt: barite; Cer: cerussite; Dol: dolomite; Fe-ox: iron oxyhydroxides (mainly goethite); Gth: goethite; Hdz: hydrozincite; Hm: hemimorphite; Sm: smithsonite.

SEM and BSE images are shown in Figures 7 and 8, respectively. Large hemimorphite crystals (Figure 7a) and botryoidal hydrozincite (Figure 8a) were covered with Feoxy-hydroxides and quartz-rich crusts. Cerussite was also detected in sample ECH 18 (Figure 8d). In samples ECH 7, ECH 15, and ECH 20, clay minerals, likely corresponding to montmorillonite, illite $( \pm \mathrm{Zn})$, or also of sauconite type $\mathrm{Zn}$-clay were detected 
(Figure 7e,f; Figure 8f). Malachite was rare, while mimetite was observed as cavity linings. Fluorite and barite laths (Figure 7f) were associated with the primary ore.
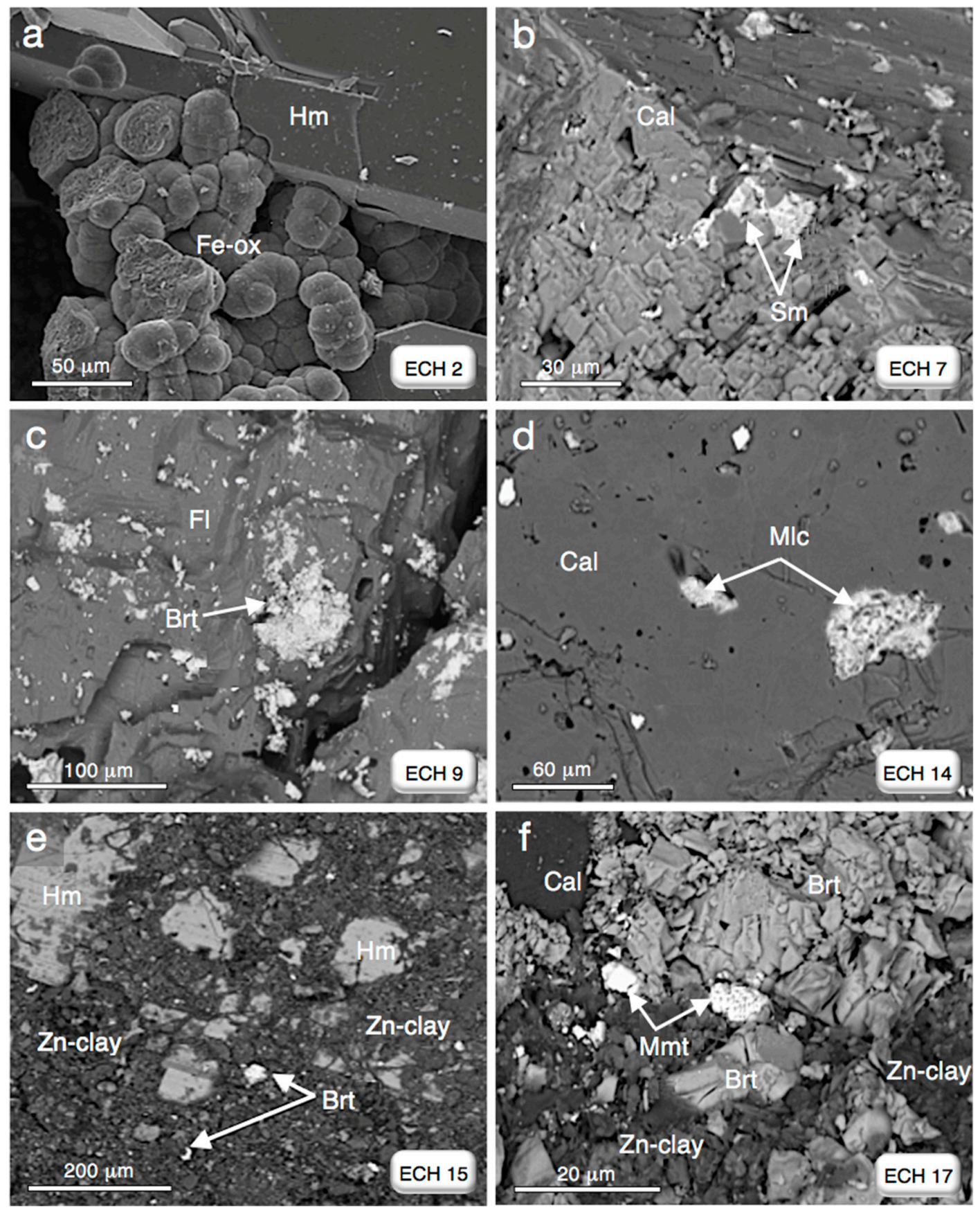

Figure 7. SEM-BSE micrographs of selected samples from the Bou Caïd orefield. (a) Large hemimorphite crystals with globular Fe-oxy-hydroxides aggregates; (b) calcite with smithsonite fillings; (c) fluorite with disseminated barite; (d) malachite in vugs of calcite; (e) hemimorphite with Zn-clays layers; (f) rare occurrence of mimetite, together with Zn-clays, calcite and barite. Brt: barite; Cal: calcite; Cer: cerussite; Fe-ox, mixed Fe-oxy-hydroxides; Fl: fluorite; Hm: hemimorphite; Mlc: malachite; Mmt: mimetite; Sm: smithsonite. 

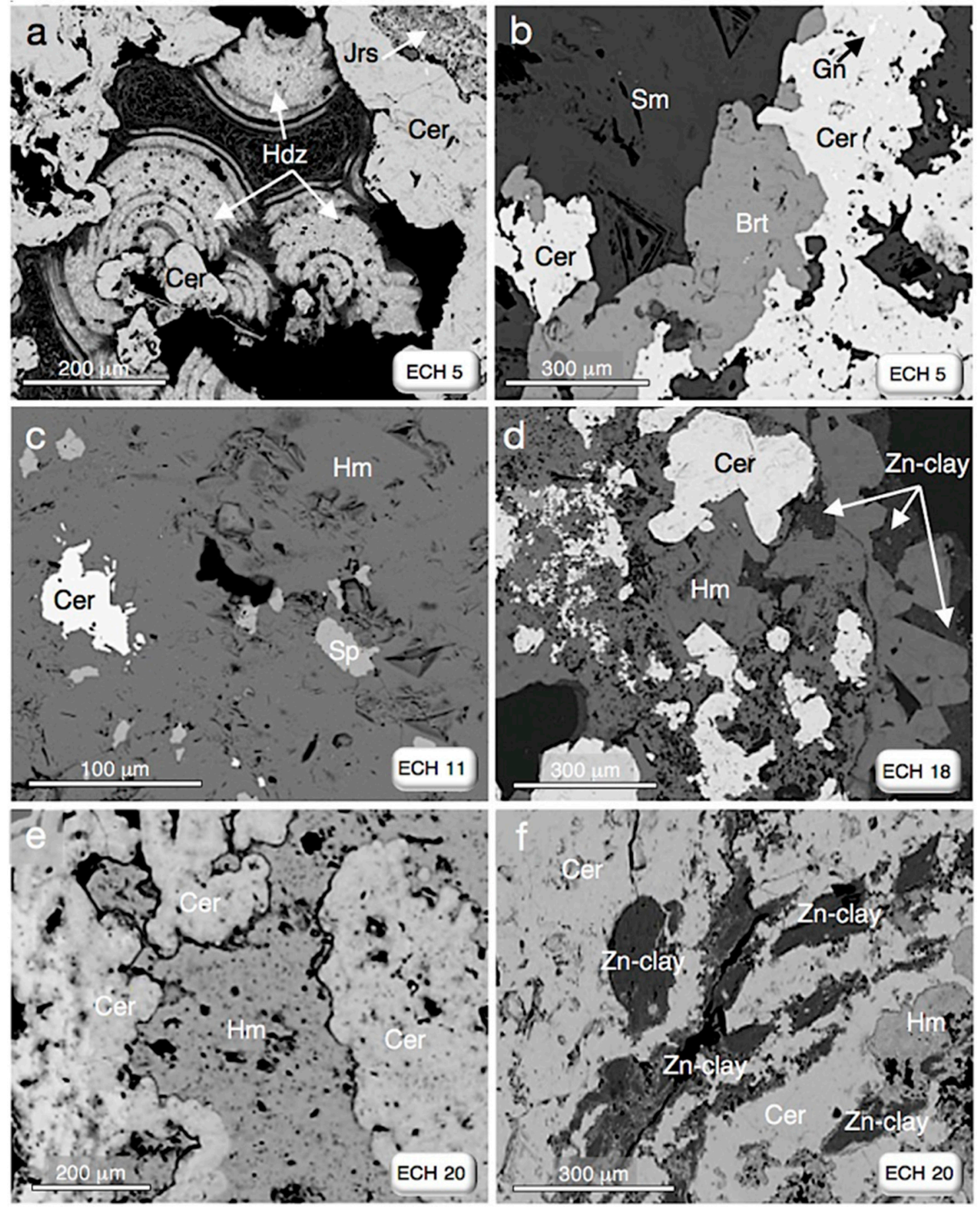

Figure 8. SEM-BSE micrographs of selected Bou Caïd samples. (a) Hydrozincite as cavity linings among cerussite crystals, with late jarosite; (b) galena remnants in cerussite, with smithsonite and barite; (c) hemimorphite and cerussite, with remnants of sphalerite; (d) euhedral hemimorphite crystals and cerussite, with late Zn-clays; (e) cerussite with hemimorphite fillings; (f) cerussite and minor hemimorphite, permeated by Zn-clays. Brt: barite; Cer: cerussite; Gn: galena; $\mathrm{Hm}$ : hemimorphite; Hdz: hydrozincite; Sm: smithsonite; Sp: sphalerite.

Selected minerals were analyzed by quantitative EDS; the chemical compositions of some supergene minerals are shown in Tables $2-4$. Hemimorphite is nearly stoichiometric, with only traces of $\mathrm{Al}, \mathrm{Ca}, \mathrm{Fe}, \mathrm{Mn}, \mathrm{Pb}$, and $\mathrm{Cd}$. Smithsonite shows only trace amounts of $\mathrm{Ca}, \mathrm{Fe}, \mathrm{Mg}, \mathrm{Cd}, \mathrm{Pb}, \mathrm{Cu}$, and As. Hydrozincite can contain small amounts of $\mathrm{Pb}(0.78-1.91$ wt.\% $\mathrm{PbO}$ ) and traces of $\mathrm{Al}, \mathrm{Ca}, \mathrm{Mn}, \mathrm{Cd}$, and As. Goethite shows significant amounts of $\mathrm{Si}$ 
(2.00-5.56 wt.\% $\left.\mathrm{SiO}_{2}\right), \mathrm{Zn}(1.16-2.10$ wt.\% $\mathrm{ZnO}), \mathrm{Pb}(0.98-1.88$ wt.\% PbO), and Al (0.16-1.33 wt. $\% \mathrm{Al}_{2} \mathrm{O}_{3}$ ), plus $\mathrm{Ca}$ and $\mathrm{Mg}$ traces. Cerussite can be nearly stoichiometric, with trace contents of $\mathrm{Si}, \mathrm{Al}, \mathrm{Zn}, \mathrm{Ca} \mathrm{Mg}$, and Mn. Illite also contained 0.86-1.39 wt.\% ZnO (Table 2). The detected smectite likely corresponds to sauconite (Zn-smectite); however, we were not able to obtain reliable analyses of this mineral.

Table 2. Chemical composition of selected silicates from the nonsulfide ore association (Hm: hemimorphite; Ilt: illite).

\begin{tabular}{|c|c|c|c|c|c|c|c|c|c|c|c|c|}
\hline & $\begin{array}{c}\mathrm{Hm} \\
\mathrm{ECH} \\
\mathbf{1}\end{array}$ & $\begin{array}{c}\mathrm{Hm} \\
\mathrm{ECH} \\
\mathbf{1}\end{array}$ & $\begin{array}{c}\mathrm{Hm} \\
\mathrm{ECH} \\
\mathbf{1}\end{array}$ & $\begin{array}{c}\mathrm{Hm} \\
\mathrm{ECH} \\
5\end{array}$ & $\begin{array}{c}\mathrm{Hm} \\
\mathrm{ECH} \\
\mathbf{1 1}\end{array}$ & $\begin{array}{c}\mathrm{Hm} \\
\mathrm{ECH} \\
12\end{array}$ & $\begin{array}{c}\mathrm{Hm} \\
\mathrm{ECH} \\
12\end{array}$ & $\begin{array}{c}\mathrm{Hm} \\
\mathrm{ECH} \\
18\end{array}$ & $\begin{array}{c}\text { Ilt } \\
\text { ECH } \\
18\end{array}$ & $\begin{array}{c}\text { Ilt } \\
\text { ECH } \\
18\end{array}$ & $\begin{array}{c}\text { Ilt } \\
\text { ECH } \\
20\end{array}$ & $\begin{array}{c}\text { Ilt } \\
\text { ECH } \\
20\end{array}$ \\
\hline $\mathrm{Si}_{2} \mathrm{O}$ & 24.50 & 25.73 & 24.73 & 25.40 & 25.67 & 26.02 & 26.53 & 25.45 & 49.04 & 47.57 & 49.13 & 44.37 \\
\hline $\mathrm{Al}_{2} \mathrm{O}_{3}$ & 0.22 & 0.09 & 0.21 & 0.09 & 0.21 & 0.33 & 0.34 & 0.54 & 23.04 & 23.92 & 22.82 & 24.66 \\
\hline $\mathrm{K}_{2} \mathrm{O}$ & 0.00 & 0.00 & 0.00 & 0.00 & 0.00 & 0.00 & 0.00 & 0.00 & 8.14 & 8.83 & 8.04 & 8.61 \\
\hline $\mathrm{ZnO}$ & 67.42 & 65.10 & 66.69 & 66.00 & 66.11 & 65.56 & 65.43 & 65.53 & 1.22 & 1.33 & 0.96 & 1.39 \\
\hline $\mathrm{CaO}$ & 0.07 & 0.00 & 0.13 & 0.16 & 0.02 & 0.00 & 0.00 & 0.10 & 0.20 & 0.24 & 0.12 & 0.16 \\
\hline $\mathrm{FeO}$ & 0.10 & 0.52 & 0.39 & 0.23 & 0.38 & 0.27 & 0.26 & 0.75 & 1.26 & 1.46 & 2.09 & 1.88 \\
\hline $\mathrm{PbO}$ & 0.20 & 0.20 & 0.00 & 0.32 & 0.18 & 0.00 & 0.28 & 0.00 & 0.00 & 0.10 & 0.00 & 0.17 \\
\hline $\mathrm{MgO}$ & 0.00 & 0.00 & 0.08 & 0.25 & 0.13 & 0.00 & 0.00 & 0.00 & 2.71 & 2.11 & 2.84 & 2.08 \\
\hline $\mathrm{MnO}$ & 0.00 & 0.00 & 0.06 & 0.00 & 0.10 & 0.67 & 0.04 & 0.02 & 0.23 & 0.38 & 0.45 & 0.2 \\
\hline $\mathrm{CdO}$ & 0.09 & 0.00 & 0.00 & 0.00 & 0.00 & 0.21 & 0.00 & 0.00 & 0.00 & 0.00 & 0.00 & 0.00 \\
\hline $\mathrm{As}_{2} \mathrm{O}_{5}$ & 0.00 & 0.00 & 0.00 & 0.30 & 0.00 & 0.00 & 0.00 & 0.00 & 0.00 & 0.00 & 0.00 & 0.00 \\
\hline Total & 92.60 & 91.64 & 92.29 & 92.75 & 92.80 & 93.06 & 92.88 & 92.39 & 85.84 & 85.94 & 86.45 & 83.52 \\
\hline
\end{tabular}

Table 3. Chemical composition of selected $\mathrm{Zn}$ - $\mathrm{Pb}$-bearing carbonates from the nonsulfide ore association (Sm: smithsonite; Hdz: hydrozincite; Cer: cerussite).

\begin{tabular}{|c|c|c|c|c|c|c|c|c|c|c|c|c|}
\hline & $\begin{array}{c}\mathrm{Sm} \\
\mathrm{ECH} \\
\mathbf{1}\end{array}$ & $\begin{array}{c}\mathrm{Sm} \\
\mathrm{ECH} \\
\mathbf{1}\end{array}$ & $\begin{array}{c}\mathrm{Sm} \\
\mathrm{ECH} \\
5\end{array}$ & $\begin{array}{c}\mathrm{Sm} \\
\mathrm{ECH} \\
5\end{array}$ & $\begin{array}{c}\mathrm{Sm} \\
\mathrm{ECH} \\
5\end{array}$ & $\begin{array}{c}\mathrm{Sm} \\
\mathrm{ECH} \\
12\end{array}$ & $\begin{array}{c}\mathrm{Sm} \\
\mathrm{ECH} \\
12\end{array}$ & $\begin{array}{c}\mathrm{Hdz} \\
\mathrm{ECH} \\
5\end{array}$ & $\begin{array}{c}\mathrm{Hdz} \\
\mathrm{ECH} \\
5\end{array}$ & $\begin{array}{c}\text { Cer } \\
\text { ECH } \\
5\end{array}$ & $\begin{array}{c}\text { Cer } \\
\text { ECH } \\
18\end{array}$ & $\begin{array}{c}\text { Cer } \\
\text { ECH } \\
18\end{array}$ \\
\hline $\mathrm{Si}_{2} \mathrm{O}$ & 0.00 & 0.00 & 0.00 & 0.04 & 0.00 & 0.00 & 0.00 & 0.68 & 0.00 & 0.00 & 0.00 & 0.57 \\
\hline $\mathrm{Al}_{2} \mathrm{O}_{3}$ & 0.00 & 0.00 & 0.00 & 0.03 & 0.21 & 0.00 & 0.00 & 0.14 & 0.00 & 0.00 & 0.00 & 0.00 \\
\hline $\mathrm{ZnO}$ & 64.59 & 63.14 & 64.12 & 63.17 & 62.34 & 64.07 & 64.40 & 73.10 & 73.44 & 0.11 & 0.42 & 0.00 \\
\hline $\mathrm{CaO}$ & 0.14 & 0.11 & 0.22 & 0.23 & 0.57 & 0.12 & 0.00 & 0.19 & 0.65 & 0.38 & 0.24 & 0.32 \\
\hline $\mathrm{FeO}$ & 0.10 & 0.56 & 0.09 & 0.83 & 0.92 & 0.24 & 0.29 & 0.00 & 0.32 & 0.25 & 0.00 & 0.00 \\
\hline $\mathrm{PbO}$ & 0.00 & 0.00 & 0.00 & 0.00 & 0.00 & 0.18 & 0.00 & 1.71 & 0.98 & 80.77 & 81.57 & 82.38 \\
\hline $\mathrm{MgO}$ & 0.14 & 0.16 & 0.31 & 0.23 & 0.32 & 0.14 & 0.00 & 0.00 & 0.18 & 0.64 & 0.16 & 0.00 \\
\hline $\mathrm{MnO}$ & 0.00 & 0.09 & 0.26 & 0.27 & 0.21 & 0.09 & 0.00 & 0.24 & 0.13 & 0.18 & 0.79 & 0.00 \\
\hline $\mathrm{CdO}$ & 0.30 & 0.24 & 0.00 & 0.00 & 0.22 & 0.00 & 0.00 & 0.04 & 0.12 & 0.00 & 0.00 & 0.00 \\
\hline $\mathrm{As}_{2} \mathrm{O}_{5}$ & 0.00 & 0.00 & 0.23 & 0.30 & 0.00 & 0.00 & 0.00 & 0.28 & 0.00 & 0.00 & 0.00 & 0.00 \\
\hline $\mathrm{CuO}$ & 0.00 & 0.00 & 0.00 & 0.00 & 0.00 & 0.75 & 0.84 & 0.00 & 0.00 & 0.00 & 0.00 & 0.00 \\
\hline $\mathrm{CO}_{2}{ }^{*}$ & 35.36 & 34.89 & 35.40 & 35.27 & 35.28 & 35.10 & 35.01 & 16.19 & 16.42 & 17.25 & 17.16 & 16.49 \\
\hline Total & 100.63 & 99.19 & 100.63 & 100.37 & 100.07 & 100.69 & 100.54 & 92.57 & 92.24 & 99.58 & 100.34 & 99.76 \\
\hline
\end{tabular}

${ }^{*}$ Calculated from stoichiometry. 
Table 4. Chemical composition of selected goethites (Gth) from the nonsulfide ore.

\begin{tabular}{cccccccc}
\hline & $\begin{array}{c}\text { Gth } \\
\text { ECH 1 }\end{array}$ & $\begin{array}{c}\text { Gth } \\
\text { ECH 1 }\end{array}$ & $\begin{array}{c}\text { Gth } \\
\text { ECH 6 }\end{array}$ & $\begin{array}{c}\text { Gth } \\
\text { ECH 11 }\end{array}$ & $\begin{array}{c}\text { Gth } \\
\text { ECH 12 }\end{array}$ & $\begin{array}{c}\text { Gth } \\
\text { ECH 20 }\end{array}$ & $\begin{array}{c}\text { Mmt } \\
\text { ECH 17 }\end{array}$ \\
\hline $\mathrm{Si}_{2} \mathrm{O}$ & 4.51 & 4.67 & 2.30 & 3.44 & 2.00 & 5.56 & 0.00 \\
$\mathrm{Al}_{2} \mathrm{O}_{3}$ & 0.15 & 1.04 & 0.40 & 0.23 & 0.16 & 0.33 & 0.00 \\
$\mathrm{ZnO}$ & 1.16 & 1.47 & 1.34 & 2.19 & 1.95 & 2.16 & 72.73 \\
$\mathrm{CaO}$ & 0.46 & 0.03 & 0.27 & 0.11 & 0.08 & 0.17 & 0.34 \\
$\mathrm{FeO}$ & 87.45 & 86.40 & 88.40 & 83.49 & 83.76 & 84.25 & 0.18 \\
$\mathrm{PbO}$ & 1.88 & 1.29 & 0.98 & 1.00 & 1.23 & 3.64 & 0.45 \\
$\mathrm{MgO}$ & 0.20 & 0.19 & 0.00 & 0.32 & 0.15 & 0.11 & 0.12 \\
$\mathrm{As}_{2} \mathrm{O}_{5}$ & 0.00 & 0.00 & 0.00 & 0.00 & 0.00 & 0.00 & 22.68 \\
$\mathrm{Cl}$ & 0.00 & 0.00 & 0.00 & 0.00 & 0.00 & 0.00 & 2.12 \\
$\mathrm{Total}$ & 95.81 & 95.09 & 93.69 & 90.78 & 89.33 & 96.22 & 98.62 \\
\hline
\end{tabular}

Carbon and oxygen isotope data are reported in Table 5. The smithsonite samples had $\delta^{13} \mathrm{C}$ and $\delta^{18} \mathrm{O}$ values between $-6.8 \%$ and $-4.3 \%$ V-PDB and -6.0 and $-4.8 \% \mathrm{~V}$ SMOW, respectively. Hydrozincite $\delta^{13} \mathrm{C}$ varies from -6.2 to $-2.7 \%$ V-PDB, while $\delta^{18} \mathrm{O}$ ranged from $20.3 \%$ to $25.3 \% \mathrm{~V}$-SMOW. $\delta^{13} \mathrm{C}$ and $\delta^{18} \mathrm{O}$ of calcites associated with the sulfide stage (hydrothermal) varied between $0.6 \%$ and $-1.0 \%$ V-PDB and $20.6 \%$ to $24.1 \%$ V-SMOW, respectively. Calcite deposited in the supergene stage showed $\delta^{13} \mathrm{C}$ and $\delta^{18} \mathrm{O}$ values in the range of $-1.6 \%$ to $-9.5 \%$ V-PDB and $18.7 \%$ to $25.2 \%$ V-SMOW, respectively. Figure 9 shows the $\delta^{13} \mathrm{C}$ vs. $\delta^{18} \mathrm{O}$ values for the carbonate samples given in Table 5. Published values for $\mathrm{Zn}$-carbonates from supergene ore deposits (calcite, dolomite, smithsonite, and hydrozincite are given for comparison [23]. The smithsonite and most of the hydrozincite carbon and oxygen isotope values plot in or close to the supergene $\mathrm{Zn}$-carbonate field. The Bou Caiid supergene calcites analyzed in this study showed negative $\delta^{13} \mathrm{C}$ values. However, those associated with primary mineralization showed positive $\delta^{13} \mathrm{C}$ values and exhibited compositions similar to other hydrothermal calcites (see for instance [27]), which partly overlap also those of the former parent rocks [28].

Table 5. Carbon and oxygen isotope compositions of selected carbonates from the Bou Caïd ores.

\begin{tabular}{|c|c|c|c|}
\hline Sample \# & Description & $\delta^{13} \mathrm{C}(\% \mathrm{~V}-\mathrm{PDB})$ & $\delta^{18} \mathrm{O}(\%$ V-SMOW) \\
\hline ECH 1 & hydrozincite & -2.80 & 24.26 \\
\hline ECH 4-1 & hydrothermal calcite & 0.61 & 22.25 \\
\hline ECH 4-2 & hydrothermal calcite & 0.98 & 22.42 \\
\hline ECH 5-1 & hydrozincite & -2.70 & 25.32 \\
\hline ECH 5-2 & smithsonite & -6.76 & 25.89 \\
\hline ECH 8 & calcite & -9.52 & 18.74 \\
\hline ECH 12 & hydrozincite & -2.84 & 23.36 \\
\hline ECH 16 dark & calcite & -2.07 & 20.08 \\
\hline ECH 16 pale & calcite & -1.56 & 20.30 \\
\hline ECH 21 & hydrothermal calcite & 0.66 & 20.60 \\
\hline ECH 22 & hydrothermal calcite & 0.88 & 23.94 \\
\hline ECH 23 & hydrothermal calcite & 0.96 & 24.10 \\
\hline ECH 24 & hydrozincite & -6.19 & 20.30 \\
\hline ECH 25 & $\begin{array}{l}\text { smithsonite with } \\
\text { hydrozincite }\end{array}$ & -4.34 & 24.64 \\
\hline CH 30 & calcite & -5.04 & 25.17 \\
\hline ECH 33 & hydrozincite & -4.95 & 24.58 \\
\hline
\end{tabular}




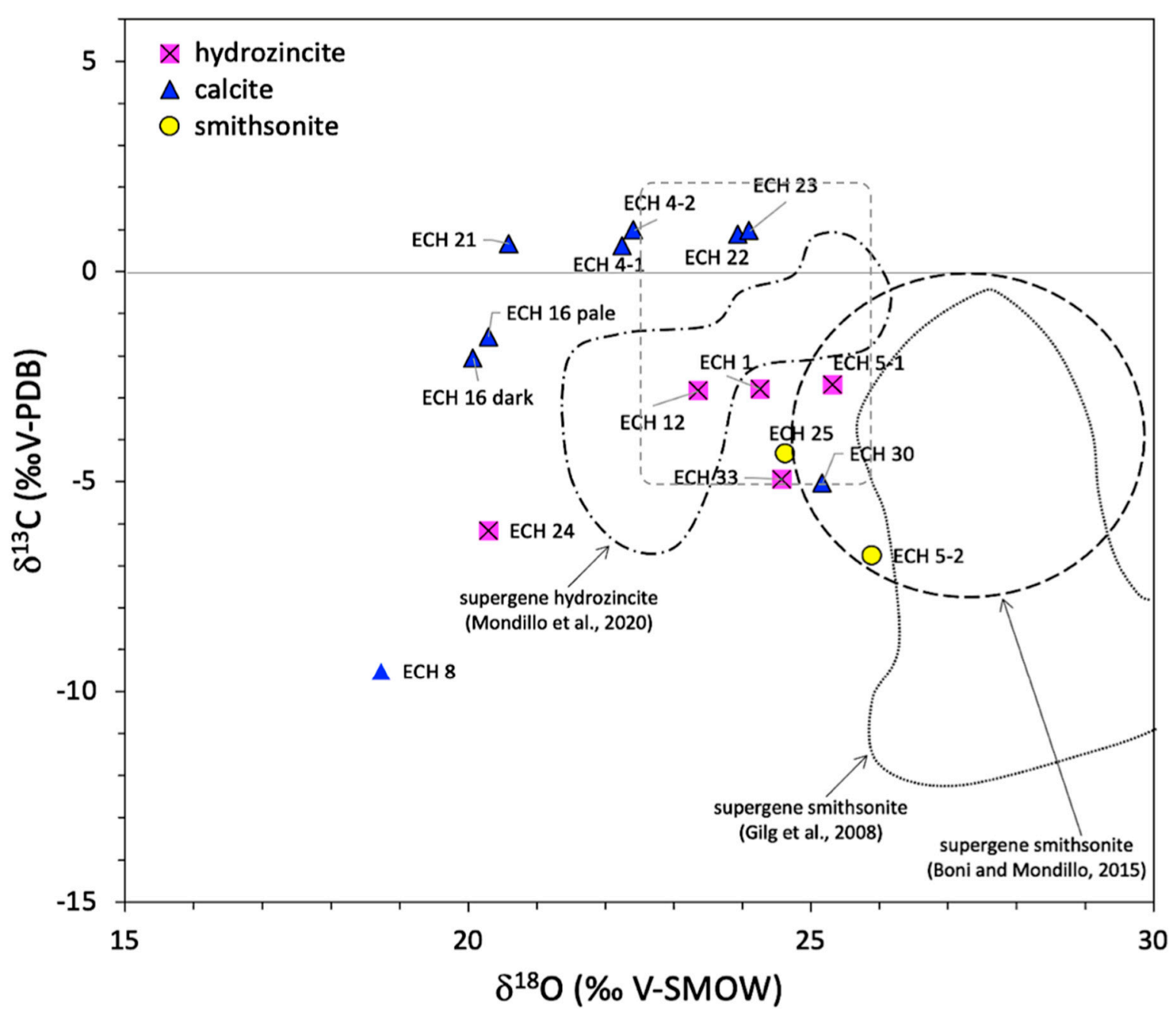

Figure 9. Carbon and oxygen isotope composition of carbonates from the Bou Caïd orefield. The fields from literature are from [23] (dotted line), [29] (dash-dotted line), [30] (dashed line), and [28] (grey dashed line).

\section{Discussion and Concluding Remarks}

This is the first study conducted on the supergene ore at Bou Caïd shows that the mineralization is composed of a mixture of hemimorphite, hydrozincite, smithsonite, cerussite, and Fe-oxy-hydroxides, often with zebra-like textures. Based on the data from this study and the publication of Louha [21], a paragenetic scheme was proposed (Figure 10). Considering the supergene mineralization phase, Louha [21] reported first the deposition of covellite and chalcocite (not detected in the samples analyzed in this study), likely due to the reduced levels of the supergene enrichment profile. Cerussite, jarosite, smithsonite, and hydrozincite follow in the paragenesis. After this group of nonsulfide minerals, hemimorphite crystallizes, accompanied by mimetite, traces of malachite and clay mineral (also $\mathrm{Zn}$-bearing) precipitation. Fe-(Mn)-oxy-hydroxides can form during various phases of the supergene stage. Small amounts of late barite can be related to partial remobilization and occur as reprecipitated products. 


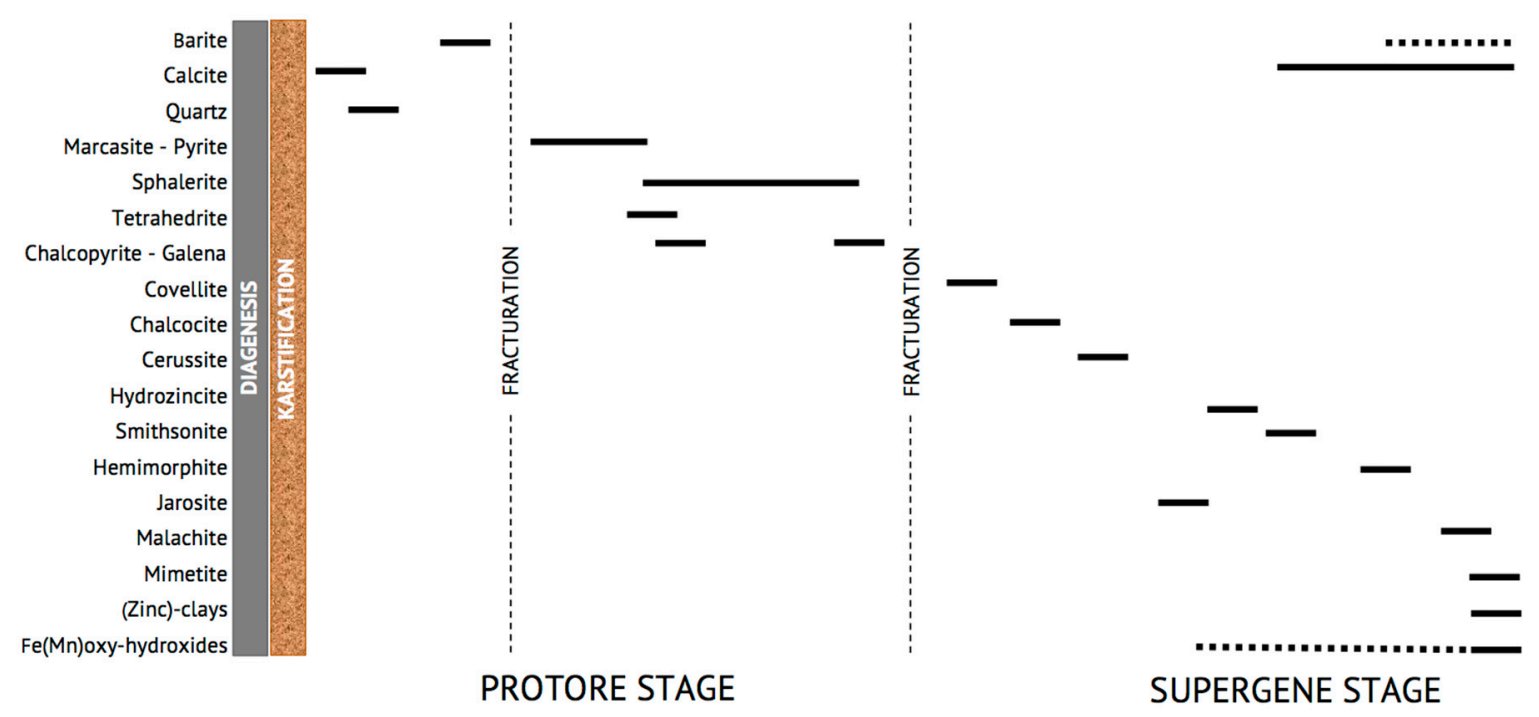

Figure 10. Mineral paragenetic sequence of $\mathrm{Ba}-(\mathrm{Zn}-\mathrm{Pb})$ primary and supergene mineralizations in the Caïd area (data of the protore stage from [21]; data of the supergene stage from [21] and this study).

Hemimorphite that crystallizes after the $\mathrm{Zn}$-bearing carbonates seems to point to an evolution toward a more silica-dominated supergene environment. Locally, Zn-bearing smectite (possibly sauconite-like) and Zn-bearing illite have also been detected; these phases are currently under investigation in order to clarify their mineralogy and the $\mathrm{Zn}$ deportment in these layered silicates. Fe-oxy-hydroxides are widespread and can be more concentrated in some parts of the orebodies. Mimetite, $\mathrm{Pb}_{5}\left(\mathrm{AsO}_{4}\right)_{3} \mathrm{Cl}$, a lead arsenate common in oxidation zones of several sulfide ores, was also detected in the Bou Caïd sample set. The occurrence of this mineral could be of interest in order to get a better indication of the As concentration in supergene systems. The restricted stability of the As-bearing minerals may play a significant role in the mobility of this element in the near-surface environment. Barite represents the primary mineralization of the Bou Caiid area; Ba sulfate detected in the supergene samples could be a result of its detrital transport or of a limited secondary remobilization/reprecipitation process.

Preliminary carbon and oxygen isotopic analyses give a further indication of the nature of the carbonate minerals. Specifically, the variation of $\delta^{13} \mathrm{C}$ and $\delta^{18} \mathrm{O}$ among the different hydrothermal calcite generations indicates that mineral precipitation was likely caused by $\mathrm{CO}_{2}$ degassing, fluid-rock interaction, or fluid mixing in an open system [27]. The low $\delta^{13} \mathrm{C}$ values might be due to the involvement of meteoric waters during the mineralization history.

Interestingly, while smithsonites show $\delta^{13} \mathrm{C}$ and $\delta^{18} \mathrm{O}$ compositions typical for supergene $\mathrm{Zn}$-carbonates [23], hydrozincite data, though characterized by negative $\delta^{13} \mathrm{C}$ values, have $\delta^{18} \mathrm{O}$ ratios that are lighter than other supergene $\mathrm{Zn}$-carbonates [23] (Figure 9). The offset in $\delta^{18} \mathrm{O}$ values must be related to the nature of the precipitating fluids that were likely characterized by varying ${ }^{18} \mathrm{O} /{ }^{16} \mathrm{O}$ ratios. Specifically, isotopically light hydrozincite formed from a fluid enriched in ${ }^{16} \mathrm{O}$. The depletion in ${ }^{18} \mathrm{O}$ in the fluid can indicate various processes, like fractionation between liquid and vapor water, Rayleigh fractionation, presence of high-temperature fluids, etc. Considering that the investigated hydrozincites are of supergene origin, it is likely that, in this case, the precipitating fluids had more or less similar ambient temperatures and were not hydrothermal. Therefore, the fluids were depleted in ${ }^{18} \mathrm{O}$ due to other processes. Similar ${ }^{18} \mathrm{O}$-depleted hydrozincites were already observed in Zn-carbonates from the Gorno mine (Italy), where they were considered as suggesting the involvement of meteoric waters subjected to Rayleigh fractionation, sourced at progressively higher elevation during the uplift of the Alps mountain chain [29]. As the Bou Caid area is located in a similar tectonic setting, at high elevation in the Algerian 
inland, it is possible that the hydrozincite compositions recorded a similar process, being precipitated from ${ }^{18} \mathrm{O}$-depleted meteoric waters.

Author Contributions: Conceptualization, G.B.; methodology, G.B. and M.M.J.; validation, G.B., M.B., M.M.J., and N.M.; formal analysis, G.B., M.M.J., and H.L.; investigation, G.B. and H.L.; data curation, G.B. and H.L.; writing—original draft preparation, G.B.; writing—review and editing, G.B., M.B., H.L., A.B., M.M.J., and N.M.; funding acquisition, G.B. All authors have read and agreed to the published version of the manuscript.

Funding: This research was funded by the University of Naples Federico II, grant "Ricerca Dipartimentale 2019" (responsible G. Balassone).

Data Availability Statement: Not applicable.

Acknowledgments: The technical support of R. de Gennaro (DiSTAR, University of Naples Federico II) for the SEM-EDS is acknowledged. We thank M.A. Morgillo for working on a set of samples for her master thesis.

Conflicts of Interest: The authors declare no conflict of interest.

\section{References}

1. Rouvier, R.; Perthuisot, V.; Mansouri, A. Pb-Zn deposits and salt bearing diapirs in Southern Europe and North Africa. Econ. Geol. 1985, 80, 666-687. [CrossRef]

2. Départment Recherches Algérie. Sur les Travaux de Prospection Géologiques Effectués sur le Gisement de l'Ouarsenis, 1968-1970; Internal Report; Départment Recherches Algérie: Algeria, 1971; p. 101.

3. Bouillin, J.P. Le bassin maghrébin: Une ancienne limite entre l'Europe et l'Afrique à l'Ouest des Alpes. Bulletin Societé Géologique de France 1986, 8, 547-558. [CrossRef]

4. Leprêtre, R.; Frizon de Lamotte, D.; Combier, V.; Gimeno-Vives, O.; Mohn, G.; Eschard, R. The Tell-Rif orogenic system (Morocco, Algeria, Tunisia) and the structural heritage of the southern Tethys margin. BSGF Earth Sci. Bull. 2018, 189, 10. [CrossRef]

5. Wildi, W. La chaine tello-rifaine (Algérie, Maroc, Tunisie): Structure, stratigraphie et évolution du Trias au Miocène. Revue de Géologie dynamique et de Géographie Physique 1983, 24, 201-297.

6. Benaouali-Mebarek, N.; Frizon de Lamotte, D.; Roca, E.; Bracène, R.; Faure, J.L.; Sassi, W.; Roure, F. Post-Cretaceous kinematics of the Atlas and Tell systems in central Algeria: Early foreland folding and subduction-related deformation. Comptes Rendus Geosci. 2006, 338, 115-125. [CrossRef]

7. Frizon de Lamotte, D.; Saint Bezar, B.; Bracène, R. Two main steps of the Atlas building and geodynamics of the Western Mediterranean. Tectonics 2000, 19, 740-761. [CrossRef]

8. Lillouch, S.; Ait Meziane, Y.; Bendadouche, H. Geotechnical cartographic synthesis of Bejaia City, north east of Algeria. J. Geol. Soc. India 2018, 91, 348-354. [CrossRef]

9. Bracène, R.; Frizon de Lamotte, D. Origin of intraplate deformation in the Atlas system of western and central Algeria: From Jurassic rifting to Cenozoic-Quaternary inversion. Tectonophysics 2002, 357, 207-226. [CrossRef]

10. Bracène, R. Géodynamique du Nord de L'Algérie: Impact sur L'exploration Pétrolière. Ph.D. Thesis, Université de Cergy Pontoise, Cergy, France, 2001; 101p.

11. Aifa, T.; Zaagane, M. Neotectonic deformation stages in the central Ouarsenis culminating zone, Northwestern Algeria. Arab. J. Geosci. 2015, 8, 2667-2680. [CrossRef]

12. Calembert, L. Étude Géologique du Massif Culminant de l'Ouarsenis. Service de la Carte Géologique d'Algérie; Bull Serv Carte Géol: Algérie, 1952; 184p.

13. Mattauer, M. Etude géologique de l'Ouarsenis oriental. Bulletin Service Carte Géologique Algérie 1958, $17,534$.

14. Tchoumatchenco, P. Brachiopodes jurassiques du Kef Sidi Amar-massif culminant de l'Ouarsenis (Algérie du Nord). Geologica Balcanica 1994, 24, 25-61.

15. Benhamou, M. Evolution Tectono-Eustatique d'un Bassin de la Téthys Maghrébine: L'Ouarsenis (Algérie) Pendant le Jurassique Inférieur et Moyen. Ph.D. Thesis, Université d'Oran, Es Senia, Algeria, 1996; 434p.

16. Benhamou, M.; Elmi, S.; Alméras, Y. Age et contexte dynamique des calcaires à brachiopodes téthysiens (Zeilleriidés multiplissés) du Grand Pic de l'Ouarsenis (Tell lgérien). Comptes Rendus Acad. Sci. 2000, 331, 717-723.

17. Tchoumatchenco, P.; Nikolov, T.; Kozhukharov, D.; Benev, B.; Gochev, P.; Katzkov, N.; Khrischev, K.; Moev, M.; Nicolov, Z.; Slavov, I.; et al. Le Crétacé inférieur dans le massif de l'Ouarsenis et les Monts de Tiaret (Algérie du Nord). Geologica Balcanica 1995, 25, 27-59.

18. Perrodon, A. Etude géologique des bassins néogènes sublittoraux de l'Algérie occidentale. Bulletin Service Carte Géologique Algérie $1957,34,382$.

19. Thomas, G. Géodynamique D’un Bassin Intra-Montagneux, le Bassin du bas Chéliff Occidental (Algérie) Durant le Mio-PlioQuaternaire. Ph.D. Thesis, Université de Pau, Pau, France, 1985; 594p. 
20. Attoucheik, L.; Jordanova, N.; Bayou, B.; Lagroix, F.; Jordanova, D.; Maouche, S.; Henry, B.; Boutaleb, A. Soil metal pollution from former $\mathrm{Zn}-\mathrm{Pb}$ mining assessed by geochemical and magnetic investigations: Case study of the Bou Caid area (Tissemsilt, Algeria). Environ. Earth Sci. 2017, 76, 298. [CrossRef]

21. Louha, H. Contribution à L'étude Gîtologique des Minéralisations du Gisement de Bou Caïd (Ouarsenis-Tissemssilt). Master's Thesis, Faculté des Sciences de la Terre de la Géographie et L'Aménagement du Territoire, Université des Sciences et de la Technologie Houari Boumediene, Bab Ezzouar, Algeria, 2012; p. 121.

22. Kim, S.T.; Mucci, A.; Taylor, B.E. Phosphoric acid fractionation factors for calcite and aragonite between 25 and $75{ }^{\circ} \mathrm{C}$, revisited. Chem. Geol. 2007, 246, 135-146. [CrossRef]

23. Gilg, H.A.; Boni, M.; Hochleitner, R.; Struck, U. Stable isotope geochemistry of carbonate minerals in supergene oxidation zones of Zn-Pb deposits. Ore. Geol. Rev. 2008, 33, 117-133. [CrossRef]

24. Mondillo, N.; Boni, M.; Balassone, G.; Villa, I.M. The Yanque Prospect (Peru): From Polymetallic Zn-Pb Mineralization to a Nonsulfide Deposit. Econ. Geol. 2014, 109, 1735-1762. [CrossRef]

25. Arfè, G.; Mondillo, N.; Boni, M.; Balassone, G.; Joachimski, M.; Mormone, A.; Di Palma, T. The karst-hosted Mina Grande nonsulfide zinc deposit, Bongará district (Amazonas region, Peru). Econ. Geol. 2017, 112, 1089-1110. [CrossRef]

26. Arfè, G.; Mondillo, N.; Boni, M.; Joachimski, M.; Balassone, G.; Mormone, A.; Santoro, L.; Castro Medrano, E. The Cristal Zn prospect (Amazonas region, Northern Peru). Part II: An example of supergene enrichments in tropical areas. Ore Geol. Rev. 2018, 95, 1076-1105. [CrossRef]

27. Zheng, Y.F.; Hoefs, J. Carbon and oxygen isotopic variations in hydrothermal calcites. Theoretical modeling on mixing processes and application to Pb-Zn deposits in the Harz Mountains, Germany. Miner. Depos. 1993, 28, 79-89.

28. Mahboubi, C.N.; Mehadji, A.O.; Chevalier, N. Microfacies and stable isotope features of the Lower-Middle Jurassic carbonate rocks of Western Saharan Atlas (Aïn Ouarka area, Algeria). Geol. J. 2021, 1-16. [CrossRef]

29. Mondillo, N.; Lupone, F.; Boni, M.; Joachimski, M.; Balassone, G.; De Angelis, M.; Zanin, S.; Granitzio, F. From Alpine-type sulfides to nonsulfides in the Gorno Zn project (Bergamo, Italy). Miner. Depos. 2020, 55, 953-970. [CrossRef]

30. Boni, M.; Mondillo, N. The "Calamines" and the "Others": The great family of supergene nonsulfide zinc ore. Ore Geol. Rev. 2015, 68, 208-233. [CrossRef] 